\title{
Incompatibility of Paracetamol with Pediatric Suspensions Containing Amoxicillin, Azithromycin and Cefuroxime Axetil
}

\author{
Hamzah Maswadeh* \\ Department of Pharmaceutics, College of Pharmacy, Qassim University, Buraydah, KSA \\ Email: *msodh@qu.edu.sa, maswadehhamza@hotmail.com
}

How to cite this paper: Maswadeh, $\mathrm{H}$. (2017) Incompatibility of Paracetamol with Pediatric Suspensions Containing Amoxicillin, Azithromycin and Cefuroxime Axetil. Pharmacology \& Pharmacy, 8, 355-368. https://doi.org/10.4236/pp.2017.811026

Received: October 12, 2017

Accepted: November 19, 2017

Published: November 22, 2017

Copyright $\odot 2017$ by author and Scientific Research Publishing Inc. This work is licensed under the Creative Commons Attribution International License (CC BY 4.0).

http://creativecommons.org/licenses/by/4.0/

\section{(c) (i) Open Access}

\begin{abstract}
The main objective of this work was to use the Differential Scanning Calorimetry (DSC) and FTIR spectroscopy to study the possible drug-drug or drug-excipient (s) interaction in case of concomitant oral administration of paracetamol with the most common used antibiotics for children. Amoxicillin, azithromycin, cefuroxime axetil and their commercially available suspensions, Amoxil ${ }^{\circledR}$, Azith$\operatorname{romax}^{\circledR}$ and Zinnat ${ }^{\circledR}$ were used. DSC curves for paracetamol, pure antibiotics, commercially available antibiotics and all binary mixtures used in this study showed drug-drug or drug-excipient (s) physical interaction and indicated a possible chemical interaction. To confirm chemical drug-drug or drug-excipient (s) interaction additional ATR-IR spectra for all samples used in this study were obtained. Results obtained from ATR-IR spectra showed drug-excipient (s) interaction in Zinnat ${ }^{\circledR}$, Azithromax ${ }^{\circledR}$ and binary mixture Azithromax ${ }^{\circledR}$-paracetamol, while chemical drug-drug interaction was not observed. From this study it can be concluded that the concomitant oral administration of paracetamol with commercially available antibiotics used in this study is not recommended and duration of two hours between the oral administrations of these drugs is strongly recommended to avoid drug-drug or drug-excipient (s) interaction.
\end{abstract}

\section{Keywords}

Paracetamol, Amoxicillin, Azithromycin, Cefuroxime Axetil, Compatibility, DSC, FTIR, Drug-Drug Interaction

\section{Introduction}

There are three classes of drug incompatibilities: therapeutic, physical and chemical. Therapeutic incompatibilities are the modification of the therapeutic effect of 
one drug by the prior concomitant administration of another. Physical incompatibilities are often called pharmaceutical incompatibilities and are evidenced by the failure of the drug to combine properly. Chemical incompatibilities occur when prescribed agents react chemically upon combination to alter the composition of one or more of the ingredients [1] [2] [3].

Compatibility studies are usually aimed at identifying the most common incompatibility, for example, an incompatibility in dosage form can be identified as any of the following changes: change in appearance, decrease in potency, loss in mechanical properties, changes in dissolution profile, loss through sublimation and increase in degradation products [4] [5] [6] [7]. A number of experimental techniques (i.e., DSC, X-ray powder diffraction, optical and Electron Microscopy, FT-IR spectroscopy, etc.) have been used to investigate the interaction between drug and excipients [8] [9] [10] [11] [12]. Differential Scanning Calorimetry is a quick technique to investigate excipient-drug incompatibility derived from the appearance, disappearance or shifts of peaks and/or variation in the corresponding $\Delta \mathrm{H}$ (enthalpy of transition). Recent study showed that the decrease in the dissolution rate of ibuprofen in ternary interactive mixture was due to the incompatibility of ibuprofen with lactose and polyvinylpyrrolidone. [13]. Previous studies showed an increase in drug dissolution by complexation with cyclodextrin corresponded with increase oral bioavailability of griseofulvin and spironolactone; but not of naproxen and tolbutamide [14] [15] [16] [17]. In one another study it was reported that release of diclofenac sodium from matrix was inhibited by polymer chitosan via formation of ionic complex between diclofenac sodium and cationic polymer [18].

Antibiotics are compounds that are used to treat infection caused by bacteria and fungi. They are very useful medications used to treat bacterial infections in children, including pneumonia, septicemia, ear infection, skin infection and meningitis. In general practice, antibiotic drug use is highest among children and approximately $70 \%$ of all antibiotics in children are prescribed for upper respiratory tract infections. Infections almost associated with fever in children, fever might rise very quickly or it might come on slowly and rise over a few days [19] [20] [21]. Doctors usually describe an antibiotic with an antipyretic drug for children and the common practice of oral administration is to administer both formulations at the same time. The suspension form is the most common formulation for antibiotics used for children present in the market and the syrup form is the most common formulation for antipyretic present in the market, both formulations containing different excipients. It is evident that the pharmaceutical manufactures provide the list of excipient (s) for each formulation and also confirm the compatibility of drug with all excipient present in the formulation. However, in case of concomitant oral administration of antibiotic formulation (suspension) with the antipyretic formulation (syrup), drug-drug or drug-excipient (s) present in the second formulation interaction may occur. In this study we investigate drug-drug or drug-excipient (present in the second for- 
mulation) compatibility in case of concomitant oral administration of paracetamol with three most common used antibiotics for children (Amoxicillin, Azithromycin and Cefuroxime axetil) by using DSC and FTIR. A comparison study between the mixtures of pure antibiotics or/commercially available antibiotic suspensions $\left(\right.$ Amoxil $^{\circledR}$, Azithromax $^{\circledR}$ and Zinnat $^{\circledR}$ ) with paracetamol was also done.

\section{Material and Methods}

\subsection{Materials}

Commercial antibiotic suspensions (Amoxil ${ }^{\circledR}$, Azithromax $^{\circledR}$ and Zinnat $^{\circledR}$ ) were purchased from the local Saudi pharmacies. Pure amoxicillin, azithromycin and cefuroxime as well as Paracetamol powders were donated by Deef (Deef, Qassim, Kingdom of Saudi Arabia).

\subsection{Methods}

\section{Preparation of Samples}

The samples were prepared by weighing $10 \mathrm{mg}$ from a mixture of paracetamol/ Pediatric suspension $(1: 1 \mathrm{w} / \mathrm{w})$ and placing it in a glass vial. The glass vial was initially turned over several times to prevent the particles from sticking to the sides of the vial and then shaken vigorously for $3 \mathrm{~min}$ by hand.

\section{Differential Scanning Calorimetry (DSC)}

The thermal profiles of all materials and mixtures used in this study were measured by DSC-60 (Shimazo, Japan) using 4 - $6 \mathrm{mg}$ of sample in open aluminum pans, with empty pan as a reference. The temperature increased with a heating rate of $10^{\circ} \mathrm{C} / \mathrm{min}$ from $30^{\circ} \mathrm{C}$ to $250^{\circ} \mathrm{C}$ under a nitrogen gas flow.

\section{FT-IR Spectroscopy}

Diamond ATR-IR spectra for paracetamol, amoxicillin, azithromycin, cefuroxime, Amoxil ${ }^{\circledR}$, Azithromax $^{\circledR}$, Zinnat $^{\circledR}$ and their mixtures were obtained over the range of $400-4000 \mathrm{~cm}^{-1}$ by using Bruker Tensor 27 FT-IR equipped with a horizontal Attenuated Total Reflectance (ATR) device with a diamond crystal. Spectra were recorded using OPUS software (Bruker Optik, Germany) by averaging 100 scans for each spectrum with resolutions of $2 \mathrm{~cm}^{-1}$. Background spectra were obtained and subtracted from each sample IR spectra.

\section{Results and Discussion}

As shown in Figure 1 pure amoxicillin exhibits a first endothermic peak appeared at $108.1^{\circ} \mathrm{C}\left(\Delta \mathrm{H}=-339.05 \mathrm{j} \mathrm{g}^{-1}\right)$, which corresponds to the dehydration of amoxicillin. The second and third endothermic peaks appeared at $195.0^{\circ} \mathrm{C}$ and $222.3^{\circ} \mathrm{C}$ attributed to the amoxicillin fusion degradation event $(\Delta \mathrm{H}=-67.13 \mathrm{j}$ $\mathrm{g}^{-1}$ and $-23.53 \mathrm{j} \mathrm{g}^{-1}$, respectively). Also, amoxicillin DSC curve displays an exothermic peak at $182.6^{\circ} \mathrm{C}$ represent the amoxicillin transition into the crystal state $\left(\Delta \mathrm{H}=19.67 \mathrm{j} \mathrm{g}^{-1}\right)$. DSC curve for the mixture of amoxicillin/paracetamol (1:1 


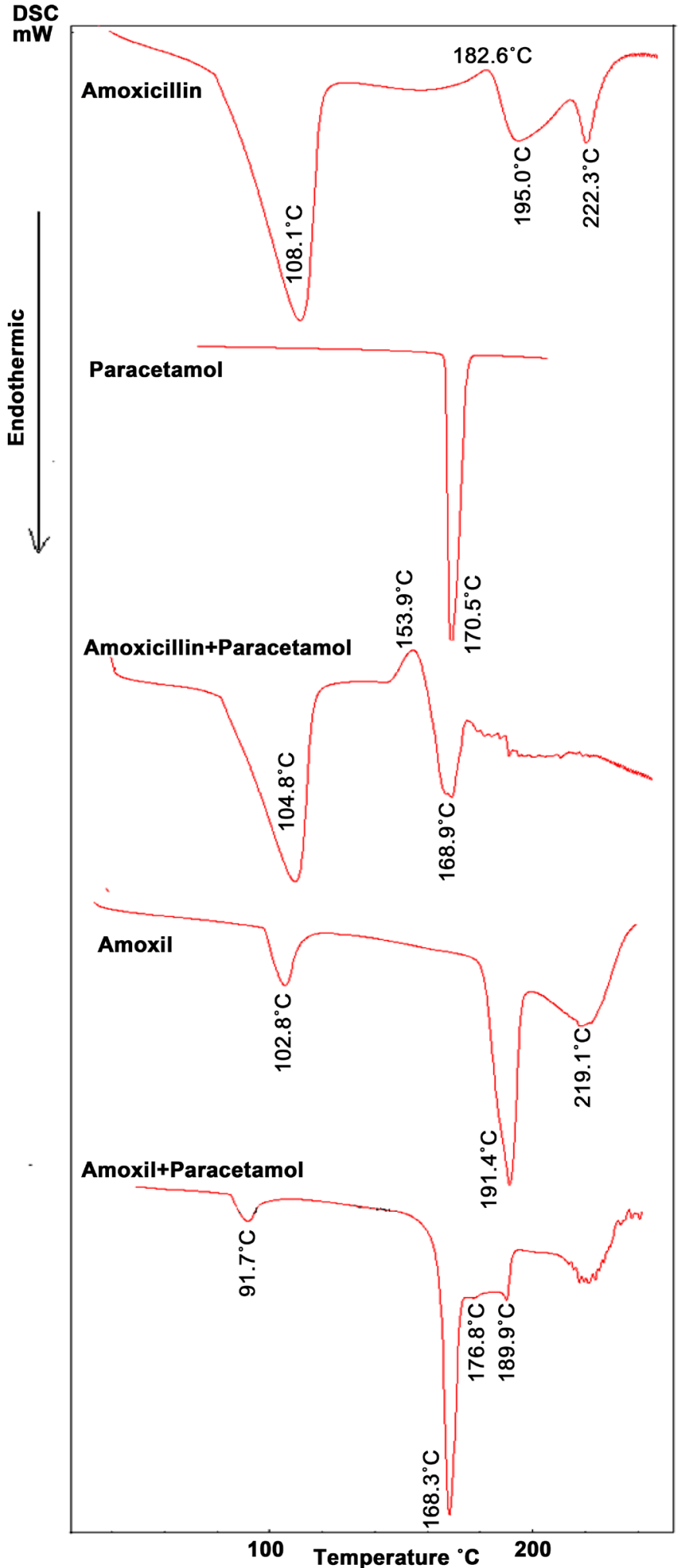

Figure 1. DSC curves for Amoxicillin, paracetamol, mixture of amoxicillin/paracetamol $(1: 1 \mathrm{w} / \mathrm{w})$, Amoxil $^{\circledR}$ and mixture of Amoxil $^{\circledR} /$ paracetamol $(1: 1 \mathrm{w} / \mathrm{w})$.

$\mathrm{w} / \mathrm{w}$ ) showed that the addition of pure paracetamol (melting peak $170.5^{\circ} \mathrm{C}$ ) to amoxicillin produced disappearance of the two endothermic peaks of amoxicillin 
observed at $195.0^{\circ} \mathrm{C}$ and $222.3^{\circ} \mathrm{C}$ and appearance of new endothermic curve with two peaks at $166.7^{\circ} \mathrm{C}$ and $168.9^{\circ} \mathrm{C}$ indicating a strong interaction between paracetamol and amoxicillin. This interaction was also associated with increase in the height of the exothermic peak that shifted to $153.9^{\circ} \mathrm{C}$. DSC curves for Amoxil ${ }^{\circledR}$ (commercially available suspension of amoxicillin for children) and a mixture of Amoxil $^{\circledR} /$ paracetamol $(1: 1 \mathrm{w} / \mathrm{w})$ were compared with DSC curves of pure amoxicillin with and without paracetamol. DSC curve for Amoxil ${ }^{\circledR}$ suspension showed three endothermic peaks at $102.8^{\circ} \mathrm{C}, 191.4^{\circ} \mathrm{C}$ and $219.1^{\circ} \mathrm{C}$, the exothermic peak of pure amoxicillin was disappeared and a small decrease of the three endothermic peaks was observed due to a possible interaction of amoxicillin with the excipient (s) present in Amoxil ${ }^{\circledR}$ suspension. Also, addition of paracetamol to Amoxil $^{\circledR}$ suspension $(1: 1 \mathrm{w} / \mathrm{w})$ showed an interaction of paracetamol with Amoxil $^{\circledR}$ suspension by decreasing the endothermic peak from $102.8^{\circ} \mathrm{C}$ to $91.7^{\circ} \mathrm{C}$ and margining of three curves (two for Amoxil ${ }^{\circledR}$ suspension and one for paraceta$\mathrm{mol}$ ) in to one broad curve with three peaks at $168.3^{\circ} \mathrm{C}, 176.8^{\circ} \mathrm{C}$ and $189.9^{\circ} \mathrm{C}$ (Figure 1).

Figure 2 shows the DSC curves for pure azithromycin, pure paracetamol, mixture of azithromycin/paracetamol $(1: 1 \mathrm{w} / \mathrm{w})$, Azithromax ${ }^{\circledR}$ suspension for children and mixture of Azithromax ${ }^{\circledR} /$ paracetamol $(1: 1 \mathrm{w} / \mathrm{w})$. DSC curve for pure azithromycin showed one small exothermic peak at $87.5^{\circ} \mathrm{C}\left(\Delta \mathrm{H}=1.50 \mathrm{j} \mathrm{g}^{-1}\right)$ and two endothermic peaks at $95.4^{\circ} \mathrm{C}\left(\Delta \mathrm{H}=-1.23 \mathrm{j} \mathrm{g}^{-1}\right)$ and $125.6^{\circ} \mathrm{C}\left(\Delta \mathrm{H}=-55.17 \mathrm{j} \mathrm{g}^{-1}\right)$. The addition of paracetamol to azithromycin produced a decrease in the endothermic peaks of azithromycin to $85.5^{\circ} \mathrm{C}$ and $123.9^{\circ} \mathrm{C}$ with disappearance of exothermic peak. Also the melting peak of paracetamol was reduced from $170.5^{\circ} \mathrm{C}$ to $160.9^{\circ} \mathrm{C}$ indicating a strong interaction between azithromycin and paracetamol. DSC curve for Azithromax ${ }^{\circledR}$ suspension (commercially available suspension of azithromycin for children) was completely different from pure azithromycin due to the presence of excipients. DSC curve for Azithromax ${ }^{\circledR}$ suspension showed that the second endothermic peak at $125.6^{\circ} \mathrm{C}$ was disappeared; also, new peaks at $69.5^{\circ} \mathrm{C}, 108.7^{\circ} \mathrm{C}, 190.4^{\circ} \mathrm{C}$ and $224.6^{\circ} \mathrm{C}$ were appeared due to the presence of excipients in Azithromax ${ }^{\circledR}$ suspension. Figure 2 showed that the addition of paracetamol to Azithromax ${ }^{\circledR}$ suspension $(1: 1 \mathrm{w} / \mathrm{w})$ produced a decrease in all endothermic peaks and an appearance of a broad curve with three peaks indicating an interaction of paracetamol with the excipient (s) present in Azithromax ${ }^{\circledR}$ suspension.

DSC curve for cefuroxime axetil showed three endothermic peaks at $85.8^{\circ} \mathrm{C}$, $\left(\Delta \mathrm{H}=-5.83 \mathrm{j} \mathrm{g}^{-1}\right) 105.2^{\circ} \mathrm{C}\left(\Delta \mathrm{H}=-6.09 \mathrm{j} \mathrm{g}^{-1}\right)$ and $181.7^{\circ} \mathrm{C}\left(\Delta \mathrm{H}=-3.08 \mathrm{j} \mathrm{g}^{-1}\right)$ which indicates that the pure drug was polymorphs (Figure 3 ). The binary mixture of paracetamol and cefuroxime axetil $(1: 1 \mathrm{w} / \mathrm{w})$ showed an increase in the first and second endothermic peaks to $86.3^{\circ} \mathrm{C}$ and $122.1^{\circ} \mathrm{C}$, respectively, while the third endothermic peak was reduced to $155.8^{\circ} \mathrm{C}$, indicating an interaction between paracetamol and cefuroxime axetil. The DSC for Zinnat ${ }^{\circledR}$ (commercially available suspension of cefuroxime for children) showed new additional endothermic peaks at $57.1^{\circ} \mathrm{C}$ and $218.5^{\circ} \mathrm{C}$ due to the presence of excipients in the formulation. 


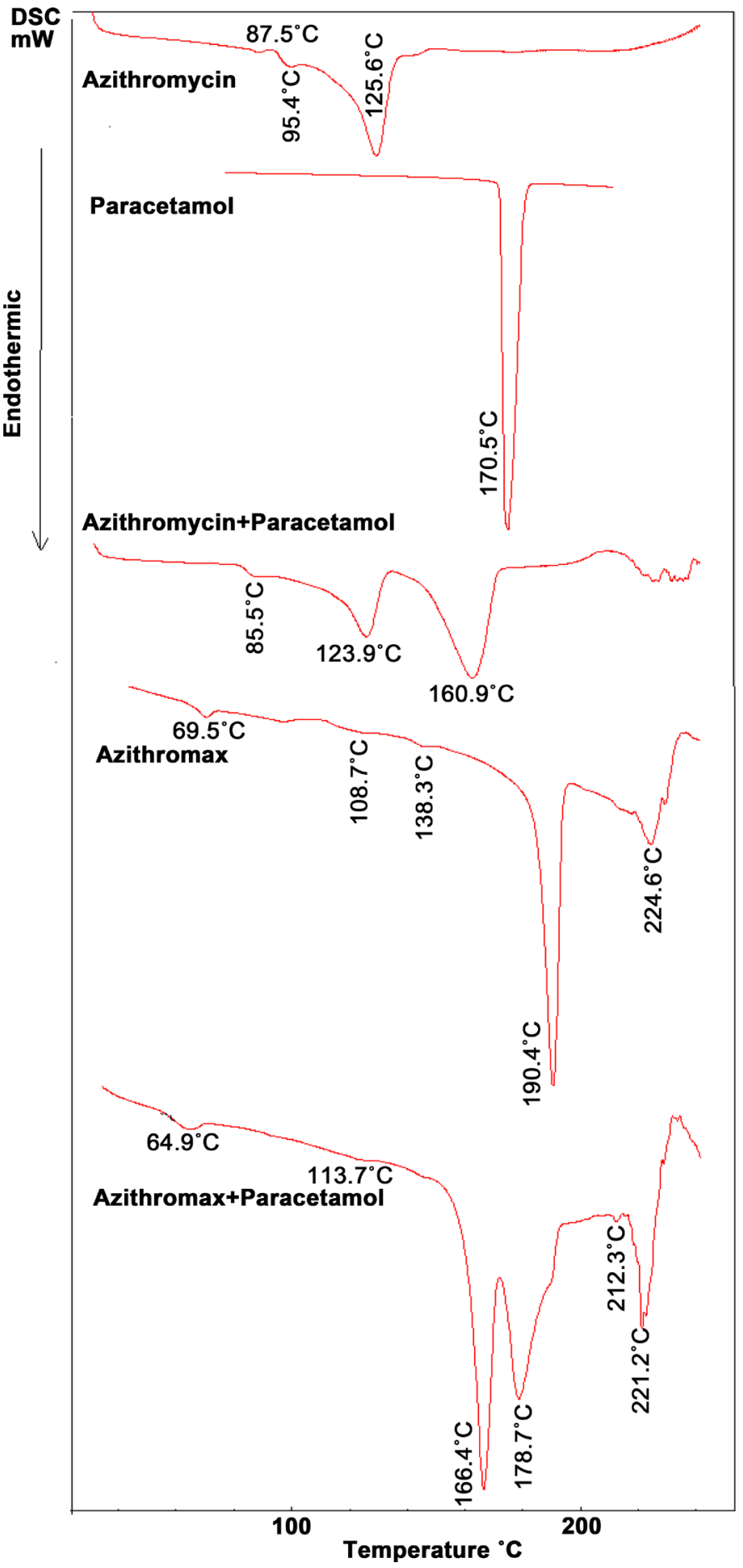

Figure 2. DSC curves for azithromycin, paracetamol, mixture of azithromycin/paracetamol

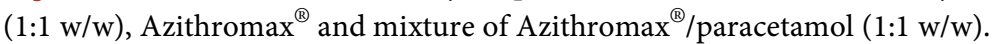

The addition of paracetamol to Zinnat ${ }^{\circledR}$ produced an appearance of new peaks at $97.0^{\circ} \mathrm{C}$ and $149.8^{\circ} \mathrm{C}$ as well as broadening and reducing the endothermic peak present at $181.8^{\circ} \mathrm{C}$ to $176.1^{\circ} \mathrm{C}$, which indicate an interaction between paracetamol and Zinnat ${ }^{\circledR}$.

DSC curves for the binary mixtures $(1: 1 \mathrm{w} / \mathrm{w})$ consist of paracetamol and pure 
antibiotics (amoxicillin, azithromycin and cefuroxime axetil) or for paracetamol and commercially available suspensions of antibiotics used for children (Amoxil ${ }^{\circledR}$, Azithromax ${ }^{\circledR}$ and Zinnat ${ }^{\circledR}$ ) showed physical drug-drug or drug-excipient (s) interaction and indicate a possible chemical drug-drug or drug-excipient (s) interaction.

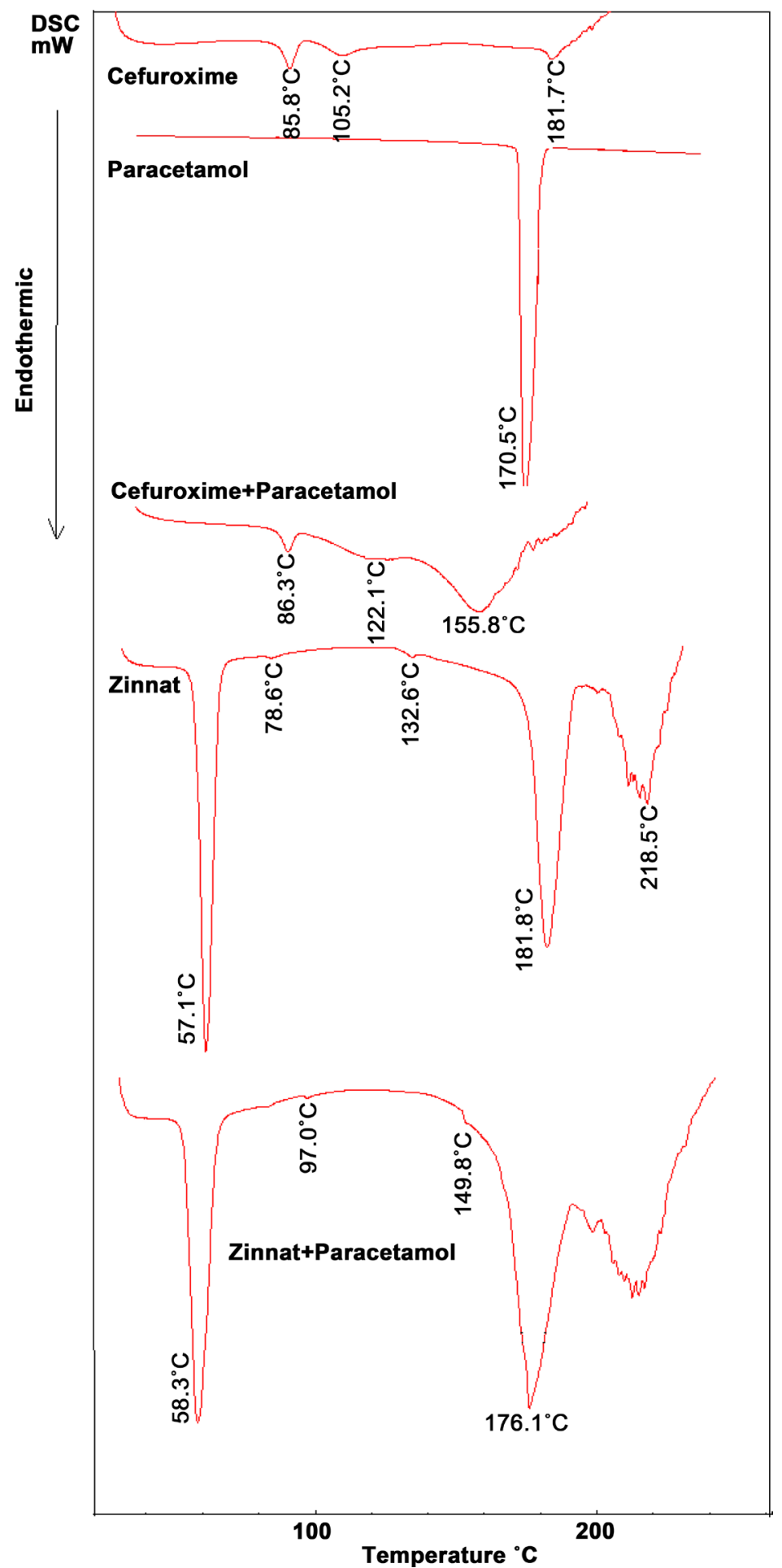

Figure 3. DSC curves for cefuroxime, paracetamol, mixture of cefuroxime/paracetamol (1:1 $\mathrm{w} / \mathrm{w})$, Zinnat ${ }^{\circledR}$, mixture of Zinnat ${ }^{\circledR} /$ paracetamol $(1: 1 \mathrm{w} / \mathrm{w})$. 
To confirm a chemical drug-drug or drug-excipient (s) interaction an additional Diamond ATR-IR spectra for paracetamol, pure antibiotics, commercially available antibiotics and all binary mixtures used in this study were obtained between 400 and $4000 \mathrm{~cm}^{-1}$ by using Bruker Tensor 27 FT-IR.

The Diamond ATR-IR spectra for pure paracetamol showed characteristic O-H, $\mathrm{N}-\mathrm{H}, \mathrm{C}=\mathrm{O}$ (amide) stretching bands at $3322.38 \mathrm{~cm}^{-1}, 3160.66 \mathrm{~cm}^{-1}$ and 1650.32 $\mathrm{cm}^{-1}$, respectively. Also, the amide II bands C-N-H group, para-disubstituted aromatic rings at $1561.34 \mathrm{~cm}^{-1}, 1258.23 \mathrm{~cm}^{-1}$ and $836.25 \mathrm{~cm}^{-1}$, respectively, were observed.

The Diamond ATR-IR spectra for pure amoxicillin showed a band at 3447.5 $\mathrm{cm}^{-1}$ (O-H, N-H stretching vibration) and characteristic peaks at $1772.78 \mathrm{~cm}^{-1}$ ( $\mathrm{C}=\mathrm{O}$ stretching of $\beta$-lactamic), $1684.94 \mathrm{~cm}^{-1}$ ( $\mathrm{C}=\mathrm{O}$ stretching of amide), 1578.05 $\mathrm{cm}^{-1}$ (asymmetric stretching of carboxylate) and $1002 \mathrm{~cm}^{-1}$ (C=O stretching vibration). The Diamond ATR-IR spectra for Amoxil ${ }^{\circledR}$ were almost same with the spectra obtained for amoxicillin as shown in Figure 4 indicating the absence of chemical drug-excipient (s) interaction in solid state.

The ATR-IR spectra for azithromycin (Figure 5) showed bands at 2782.8 $2971.0 \mathrm{~cm}^{-1}$ and $1376.89 \mathrm{~cm}^{-1}$ related to the axial stretching and bending of $\mathrm{C}-\mathrm{H}$ of the methyl groups. The axial stretching of the $\mathrm{C}=\mathrm{O}$ was observed at 1719.86 $\mathrm{cm}^{-1}$. Other bands in the spectrum in the range of $1123.16-1250.52 \mathrm{~cm}^{-1}$ were appeared due to the absorption associated to the axial stretching of C-O. Also, ATR-IR spectra in Figure 5 for the mixture of azithromycin/paracetamol (1:1 $\mathrm{w} / \mathrm{w})$ showed all characteristic peaks of both drugs without any significant shift indicates the absence of drug-drug interaction in solid state.

The ATR-IR spectra for Azithromax ${ }^{\circledR}$ showed the appearance of new peaks at $3384.40 \mathrm{~cm}^{-1}$ and $3330.55 \mathrm{~cm}^{-1}$ as well as the disappearance of some azithromycin peaks at $3488.84 \mathrm{~cm}^{-1}, 2913.17 \mathrm{~cm}^{-1}, 1719.86 \mathrm{~cm}^{-1}, 1653.29 \mathrm{~cm}^{-1}$ and 1558.47 $\mathrm{cm}^{-1}$ indicating that azithromycin was interacted with the excipients present in Azithromax ${ }^{\circledR}$ suspension (Figure 5). The ATR-IR spectra for the mixture azith$\operatorname{romax}^{\circledR} /$ paracetamol $(1: 1 \mathrm{w} / \mathrm{w})$ showed the appearance of large number of new peaks at $3649.12 \mathrm{~cm}^{-1}-3902.61 \mathrm{~cm}^{-1}, 2360.32 \mathrm{~cm}^{-1}, 2341.48 \mathrm{~cm}^{-1}$ and 1868.53 $\mathrm{cm}^{-1}-1683.49 \mathrm{~cm}^{-1}$ indicating a strong interaction in solid state between paracetamol and excipients present in Azithromax ${ }^{\circledR}$ suspension.

The ATR-IR spectra for cefuroxime axetil (Figure 6) showed characteristic NH stretching, $\beta$-lactam $\mathrm{C}=\mathrm{O}$ stretching, amide $\mathrm{C}=\mathrm{O}$ stretching and carboxylate stretching $\mathrm{O}=\mathrm{C}=\mathrm{O}$ at $3295.52 \mathrm{~cm}^{-1}, 1728.45 \mathrm{~cm}^{-1}, 1676.00 \mathrm{~cm}^{-1}$ and $1595.80 \mathrm{~cm}^{-1}$, respectively. The ATR-IR spectra for the mixture of cefuroxime axetil/paracetamol $(1: 1 \mathrm{w} / \mathrm{w})$ showed all characteristic peaks of both drugs without any significant shift indicates the absence of drug-drug interaction in solid state.

The ATR-IR spectra (Figure 6) for Zinnat ${ }^{\circledR}$ showed that new peaks were appeared at $3562.37 \mathrm{~cm}^{-1}, 3332.40 \mathrm{~cm}^{-1}, 2955.11 \mathrm{~cm}^{-1}, 2915.23 \mathrm{~cm}^{-1}, 2848.12 \mathrm{~cm}^{-1}$, $2359.63 \mathrm{~cm}^{-1}, 1734 \mathrm{~cm}^{-1}$ and $1698.57 \mathrm{~cm}^{-1}$ duo to the presence of some excipients in Zinnat ${ }^{\circledR}$ suspension. Also, the disappearance of some peaks $\left(3295.52 \mathrm{~cm}^{-1}, 2940.61\right.$ $\mathrm{cm}^{-1}, 1728.45 \mathrm{~cm}^{-1}, 1676.0 \mathrm{~cm}^{-1}$ and $1595.80 \mathrm{~cm}^{-1}$ ) of pure cefuroxime axetil from 
Zinnat ${ }^{\circledR}$ spectra indicates drug-excipient (s) interaction. The ATR-IR spectra obtained for the mixture of paracetamol/Zinnat ${ }^{\circledR}(1: 1 \mathrm{w} / \mathrm{w})$ showed no interaction between paracetamol and Zinnat ${ }^{\circledR}$ in solid state.

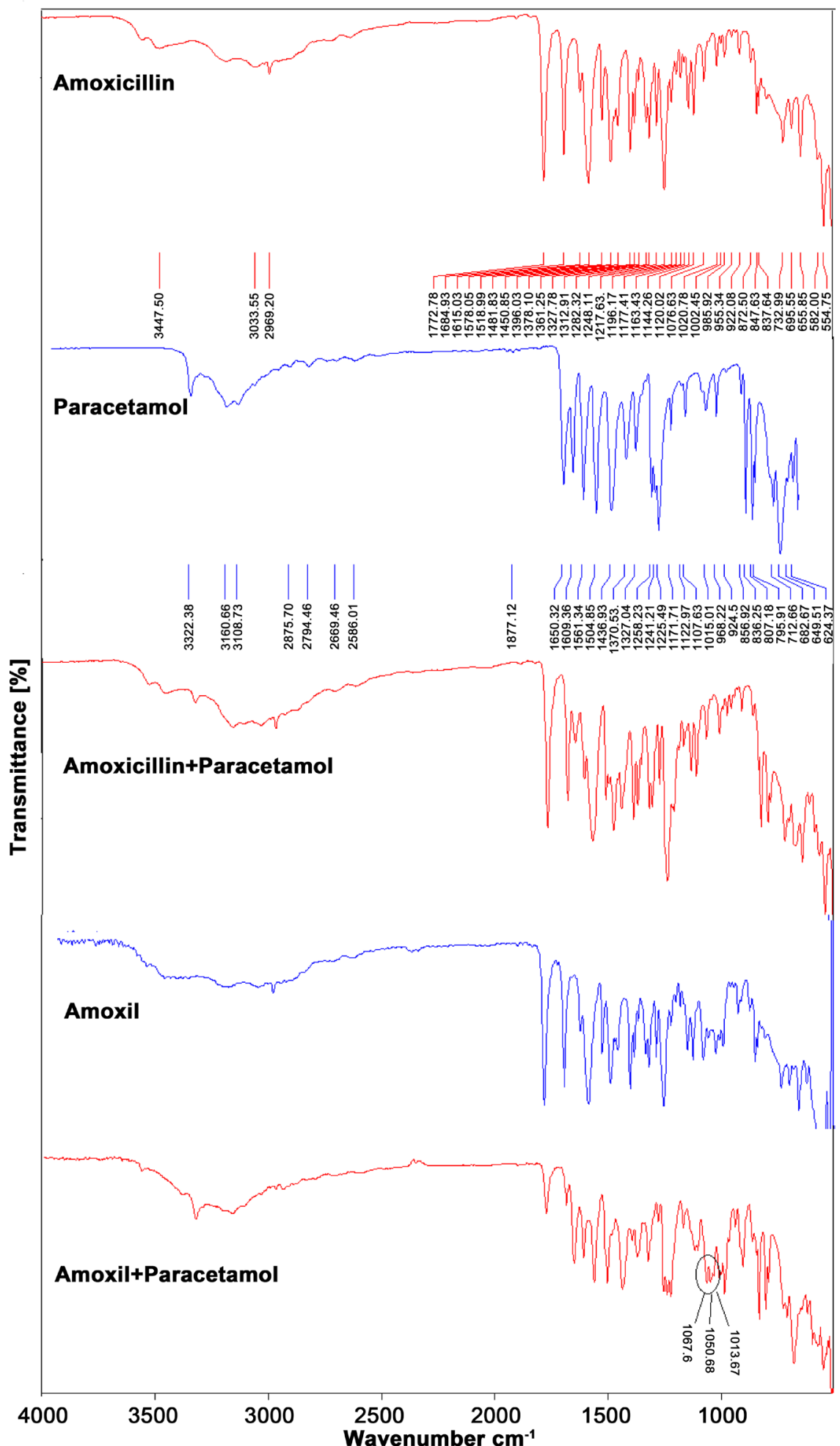

Figure 4. Diamond ATR-IR spectra for amoxicillin, paracetamol, mixture of amoxicillin/ paracetamol (1:1 w/w), Amoxil ${ }^{\circledR}$ and mixture of Amoxil ${ }^{\circledR} /$ paracetamol (1:1 w/w). 


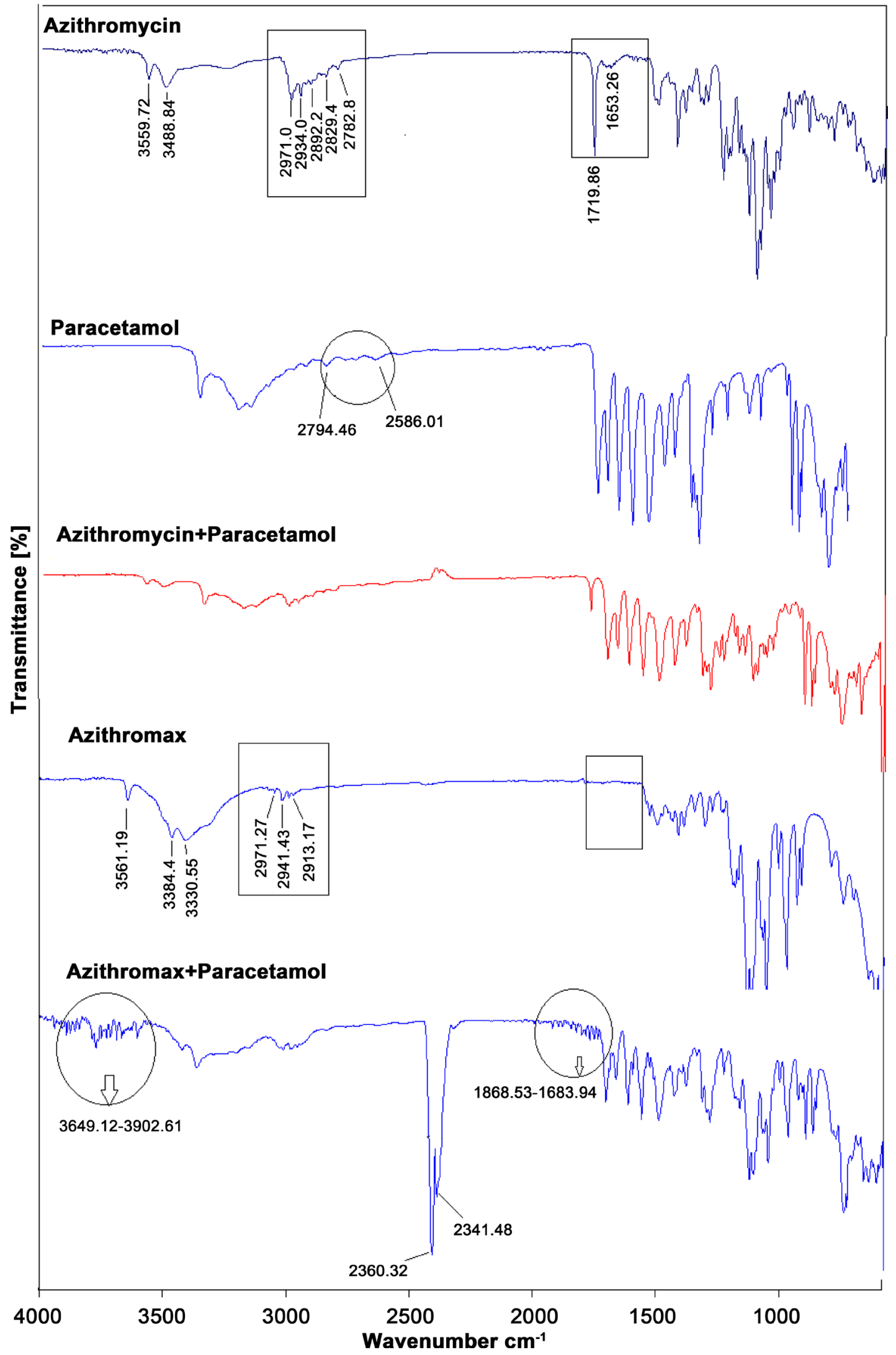

Figure 5. Diamond ATR-IR spectra for azithromycin, paracetamol, mixture of azithromycin/paracetamol (1:1 $\mathrm{w} / \mathrm{w})$, Azithromax $^{\circledR}$, mixture of Azithromax ${ }^{\circledR} /$ paracetamol $(1: 1 \mathrm{w} / \mathrm{w})$. 


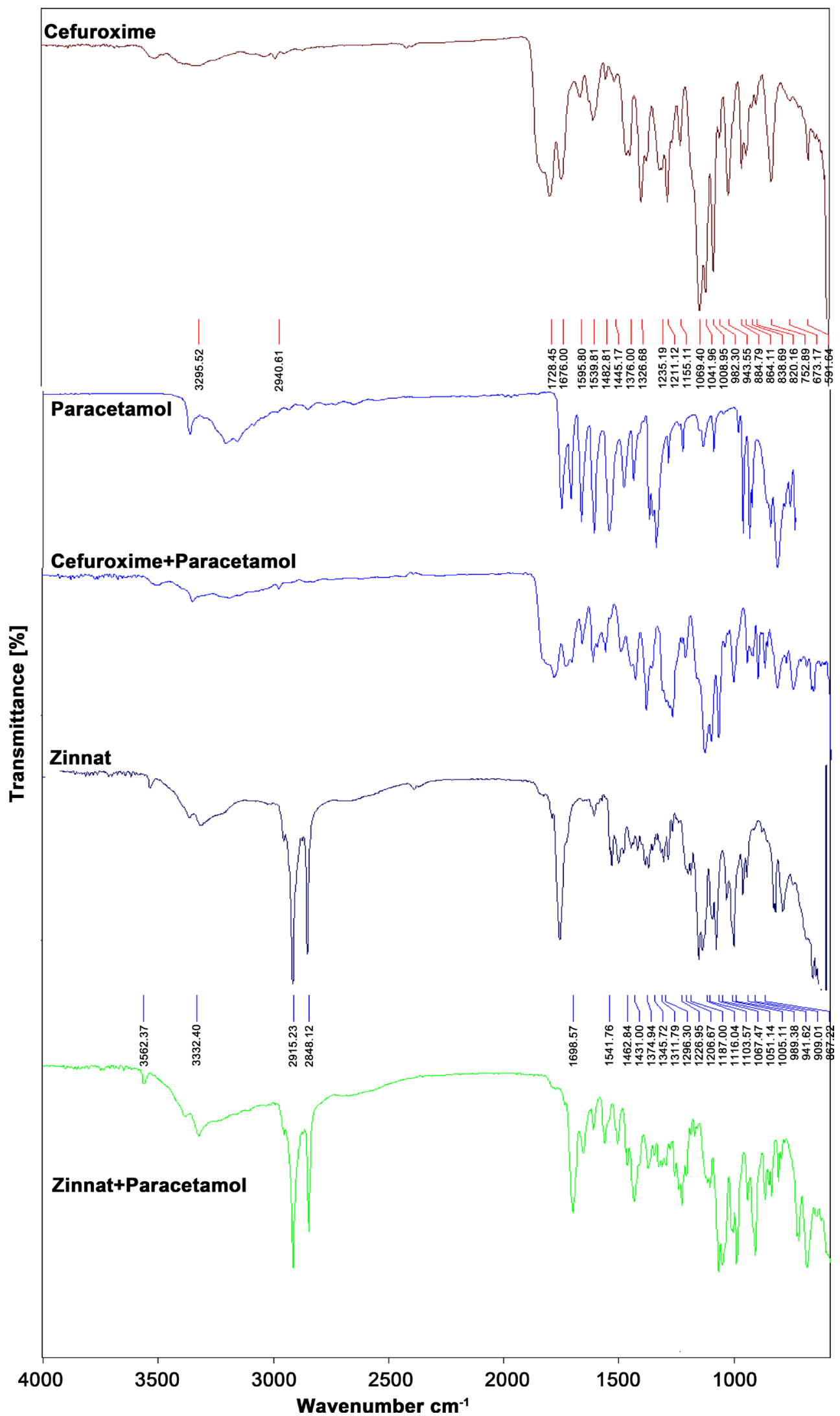

Figure 6. Diamond ATR-IR spectra for cefuroxime, paracetamol, mixture of cefuroxime/paracetamol $(1: 1 \mathrm{w} / \mathrm{w})$, Zinnat $^{\circledR}$, mixture of Zinnat ${ }^{\circledR} /$ paracetamol $(1: 1 \mathrm{w} / \mathrm{w})$. 
Table 1. Excipient present in each product as listed from the manufacturer.

\begin{tabular}{cl}
\hline Product & \multicolumn{1}{c}{ Excipients } \\
\hline Amoxil $^{\circledR}$ & $\begin{array}{l}\text { Maltodextrin (glucose), carboxymethylcellulose Sodium, lemon-Peach-Strawberry, } \\
\text { dry flavor, crospovidone, aspartame (E951), sodium benzoate (E211), xanthan Gum } \\
\text { (E415), silica hydrophobic colloidal, magnesium Stearate }\end{array}$ \\
Zinnat $^{\circledR}$ & $\begin{array}{l}\text { Aspartame, xanthan gum, acesulfame potassium, povidone K30 stearic Acid, sucrose, } \\
\text { tutti frutti flavor, purified water, sucrose }\end{array}$ \\
Azithromax $^{\circledR}$ & $\begin{array}{l}\text { Hydroxypropylcellulose, sodium phosphate tribasic anhydrous, sucrose, xanthan } \\
\text { gum, artificial banana, artificial cherry, artificial creme de vanilla }\end{array}$ \\
\hline
\end{tabular}

It is important to note that the three commercial products Amoxil ${ }^{\circledR}$, Azithro$\max ^{\circledR}$ and Zinnat ${ }^{\circledR}$ containing deferent types of excipients as shown in Table 1. The large number of additives present in the products used in this study enhances the possibility of drug-excipient (s) interaction between paracetamol and excipient (s) present in the pediatric suspension of antibiotic.

\section{Conclusion}

The DSC curves for the mixtures of paracetamol with most common used antibiotics for children (pure or commercially available suspensions) showed physical interaction. While chemical interaction in solid state (drug-excipients) was observed by FTIR for Zinnat ${ }^{\circledR}$ (cefuroxime-excipients), Azithromax ${ }^{\circledR}$ (azithromycinexcipients) and mixture of Azithromax ${ }^{\circledR}$-paracetamol (paracetamol-excipients interaction). Results obtained from FTIR showed that drug-drug interaction was not occurring. However, physical or chemical interaction in case of concomitant oral administration of paracetamol with most common used antibiotic for children may affect the physicochemical properties, dissolution rate, solubility, absorption and bioavailability for one or for both drugs. From this study it can be concluded that the concomitant oral administration of paracetamol with antibiotics used in this study is not recommended and duration of two hours between the oral administrations of these drugs is strongly recommended to avoid drug-drug or drug-excipient (s) interaction.

\section{References}

[1] Bruni, G., Amici, L., Berbenni, V., Marini, A. and Orlandi, A. (2002) Drug-Excipient Compatibility Studies. Search of Interaction Indicators. Journal of Thermal Analysis and Calorimetry, 68, 561-573. https://doi.org/10.1023/A:1016052121973

[2] Kishore, K.H., Swapan, R. and Veerappan, S. (2016) Drug-Excipient Interactions: Case Studies and Overview of Drug Degradation Pathways. American Journal of Analytical Chemistry, 7, 107-140. https://doi.org/10.4236/ajac.2016.71011

[3] Ajit, S.N., Divyakant, D. and Sherif, B. (2012) Impact of Excipient Interaction on Solid Dosage Form Stability. Pharmaceutical Research, 29, 2660-2683. https://doi.org/10.1007/s11095-012-0782-9

[4] Pani, N., Nath, L., Acharya, S. and Bhuniya, B. (2012) Application of DSC, IST, and FTIR Study in the Compatibility Testing of Nateglinide with Different Pharmaceutical Excipients. Journal of Thermal Analysis and Calorimetry, 108, 219-226. https://doi.org/10.1007/s10973-011-1299-x 
[5] Mura, P., Manderioli, A., Bramanti, G., Furlanetto, S. and Pinzauti, S. (1995) Utilization of Differential Scanning Calorimetry as a Screening Technique to Determine the Compatibility of Ketoprofen with Excipients. International Journal of Pharmaceutics, 119, 71-79. https://doi.org/10.1016/0378-5173(94)00374-E

[6] Botha, S.A. and Lotter, A.P. (1990) Compatibility Study between Oxprenolol Hydrochloride, Temazepam and Tablet Excipients Using Differential Scanning Calorimetry. Drug Development and Industrial Pharmacy, 16, 331-345. https://doi.org/10.3109/03639049009114889

[7] Marini, A., Berbenni, V., Pegoreti, M., Bruni, G., Cofrancesco, P., Sinistri, C. and Villa, M. (2003) Drug Excipient Compatibility Studies by Physic Chemical Techniques. The Case of Atenolol. Journal of Thermal Analysis and Calorimetry, 73, 547-561. https://doi.org/10.1023/A:1025478129417

[8] Misra, M., Misra, A.K. and Panpalia, G.M. (2007) Interaction Study between Pefloxacin Mesilate and Some Diluents Using DSC Supported with Isothermal Method. Journal of Thermal Analysis and Calorimetry, 89, 803-808. https://doi.org/10.1007/s10973-007-8531-8

[9] Maswadeh, H. (2016) Dissolution and Compatibility Study of Binary and Ternary Interactive Mixtures of Indomethacin: Comparison with Commercially Available Capsules. Acta Poloniae Pharmaceutica, 73, 739-748.

[10] Sarisuta, N., Lawanprasert, P., Puttipipatkhachorn, S. and Srikummoon, K. (2006) The Influence of Drug-Excipient and Drug-Polymer Interactions on Butt Adhesive Strength of Ranitidine Hydrochloride Film-Coated Tablets. Drug Development and Industrial Pharmacy, 32, 463-471. https://doi.org/10.1080/03639040500528962

[11] Sekizaki, H., Danjo, K., Eguchi, H., Yonezawa, Y., Sunada, H. and Otsuka, A. (1995) Solid State Interaction of Ibuprofen with Polyvinyl-Pyrrolidone. Chemical and Pharmaceutical Bulletin, 43, 988-992. https://doi.org/10.1248/cpb.43.988

[12] Bogdanova, S., Pajeva, I., Nikolova, P., Tsakovska, I. and Muller, B. (2005) Interaction of pol (vinylpyrrolidone) with Ibuprofen and Naproxen: Experimental and Modeling Studies. Pharmaceutical Research, 22, 806-815.

https://doi.org/10.1007/s11095-005-2598-3

[13] Maswadeh, H. (2016) Incompatibility Study of Ibuprofen in Ternary Interactive Mixture by using Differential Scanning Calorimetry. Journal of Thermal Analysis and Calorimetry, 123, 1963-1971. https://doi.org/10.1007/s10973-015-4773-Z

[14] Dhanaraju, M.D., Santil, K., Baskaran, T. and Moorthy, M.S.R. (1998) Enhancement of Bioavailability of Griseofulvin by Its Complexation with Beta Cyclodextrin. Drug Development and Industrial Pharmacy, 24, 583-587.

https://doi.org/10.3109/03639049809085663

[15] Kaukonen, A.M., Kilpeläinen, I. and Mannerma, J.P. (1997) Water-Soluble B-Cyclodextrins in Paediatric Oral Solutions of Spironolactone: Solubilization and Stability of Spironolactone in Solutions of B-Cyclodextrin Derivatives. International Journal of Pharmaceutics, 159, 159-170.

[16] Otero, E., Anguiano, I.S., Garcia, G.N., Vila, J.L. and Blanco, M.J. (1992) Interaction of Naproxen with $\beta$-Cyclodextrin in Solution and in the Solid State. International Journal of Pharmaceutics, 79, 149-157.

[17] Kedzierewicz, F., Zinutti, C., Hoffman, M. and Maincent, P. (1993) Bioavailability Study of Tolbutamide b-Cyclodextrin Inclusion Compounds, Solid Dispersions and Bulk Powder. International Journal of Pharmaceutics, 94, 69-74.

[18] Ac-ikgoz, M., Kas, H.S., Hascelik, Z., Milli, U. and Hincal, A.A. (1995) Chitosan Microspheres of Diclofenac Sodium, II: In Vitro and in Vivo Evaluation. Pharmazie, 50, 275-277. 
[19] Majeed, A. and Moser, K. (1999) Age- and Sex-Specific Antibiotic Prescribing Patterns in General Practice in England and Wales in 1996. British Journal of General Practice, 49, 735-736.

[20] Vaccheri, A., Castelvetri, C. and Esaka, E. (2000) Pattern of Antibiotic Use in Primary Health Care in Italy. European Journal of Clinical Pharmacology, 56, 417-425. https://doi.org/10.1007/s002280000165

[21] Nyquist, A.C., Gonzales, R. and Steiner, J.F. (1998) Antibiotic Prescribing for Children with Colds, Upper Respiratory Tract Infections, and Bronchitis. Journal of the American Medical Association, 279, 875-877.

https://doi.org/10.1001/jama.279.11.875 